Egypt. Acad. J. Biolog. Sci., 4 (1): 23- 33 (2012)

Email: egyptianacademic@yahoo.com

Received: 21 / 8/ 2012
F. Toxicology \&Pest control

ISSN: 2090 - 0791

www.eajbs.eg.net

\title{
Effect of katel-sous dust and clove powder and their mixtures on the cowpea seed beetle, Callosobruchus maculatus (F.) (Coleoptera: bruchidae)
}

\author{
Rasha, F. Sokker ${ }^{1}$, Mohamed, A. Hussein ${ }^{2}$, Salwa, M. S. Ahmed ${ }^{1}$ and \\ Ragaa, K. A. Hamed ${ }^{2}$ \\ 1-Plant Protection Research Institute, Stored Products Department, Agriculture \\ Research Center. \\ 2- Faculty of science, Entomology Department, Ain Shams University.
}

\begin{abstract}
The present work was carried out to evaluate the toxicity of katel-sous dust and clove powder and its combinations. Evaluation has been conducted on Callosobruchus maculatus (F.) adults to determine the toxicological effect and the changes in insect biology caused by these products. The results referred to the availability to use these products to control cowpea seed beetle and consider clove powder as spiracle-blocking insecticides. Clove powder and katel-sous dust and its combinations made a sharp reduction in the number of eggs laid and the number of adults emerged. Mixing clove powder with katel-sous dust was helping in using katelsous dust in pest management without any problems such as; its high concentration which caused suffering from the expensive costs and hardly remove the dust.
\end{abstract}

Key words: Katel-sous, Clove powder, Control, Bruchids, Coleoptera, Callosobruchus maculatus, Cowpea seed beetle and Scanning.

\section{INTRODUCTION}

Pulses are important sources of proteins, fats, carbohydrates, sugars, vitamin $B$ and minerals. The infestation of leguminous seeds with any kind of bruchid species caused an increase in both weight loss and moisture content of the infested seeds (El- Bandy et al. 1985).

The pulse beetle, Callosobruchus maculatus Fab. (Coleoptera: Bruchidae), is a major pest of economically important leguminous seeds, such as cowpeas, lentils, green gram, and black gram (Park et al. 2003).

The amount of annual loss reached $24 \%$ of stored pulses due to infestation of Callosobruchus maculatus (Caswell, 1968). During the storage, the cowpea weevil causes heavy qualitative and quantitative losses. Caswell (1981).

Using plants with insecticidal properties is therefore an attractive to the more expensive and unpleasant pesticides. Various plant products have been used recently with a good degree of success as protectants against a number of stored grain insect pests (Dixit and Saxena 1990).

Inert materials are the oldest and most widely used method of protecting grains in many countries (e.g. Egypt and India). Their mode of action on various stored grain insects was studied by (Alexander et al., 1944 and Wigglesworth, 1944) who showed that inert dusts make insects lose their body water and thus die by desiccation.

The objective of the present study is to minimize the usage of chemical control of stored legume insect pests by evaluating the efficacy of some safety control measures against one of serious stored grain pest, Callosobruchus maculatus, by using clove (Eugenia aromatica) powder and katel-sous dust as grain protectants and try to use their combinations. 


\section{MATERIALS AND METHODS Insect Culture:}

Adults (1-2 days old) of cowpea beetle, Callosobruchus maculatus (F.) used in this study were obtained from a laboratory colony, established and maintained on cowpea seeds kept under laboratory conditions of $27 \pm 3^{\circ} \mathrm{c}$ and 65 $\pm 5 \% \mathrm{RH}$ in Stored Grains pest Research Department, Plant Protection Research Institute, Agriculture Research Center, Dokki, Giza, Egypt.

Plant Materials:

Two plant materials clove powder obtained from the market and Katel-sous dust (contains $84 \%$ calcium triphosphate plus $16 \%$ sulpher, produced by Kafr ElZayat Company for Pesticides- Egypt).

Toxicological evaluation of katel-sous dust and clove powder and its mixtures on Callosobruchus maculatus adults:

Evaluation the toxicity of katel-sous dust and clove powder:

To estimate the percentage mortality which is caused by using the tested materials, five different concentrations from katel-sous dust and clove powder were evaluated to determine the efficiency of these compounds. Every concentration for each treatment was added to 10 grams of cowpea seeds in $1 \times 7.5 \mathrm{~cm}$ glass tube and was infested by 25 adults of the tested insect. Three replicates were made for each concentration and kept at $27 \pm{ }^{\circ} \mathrm{C}$ and $65 \pm 5 \%$ RH. Mortality counts of Callosobruchus maculatus adults were recorded in all experimental treatments after 1 day, 2 days, 3 days and 5 days from exposure. Percentage mortality were taken after 48 hours and were calculated and corrected according to Abbott's formula (1925) before probit statistical analysis.

\section{Experimental design and analysis of}

data:

The experiments in each set were designed to provide concentration mortality regression lines for tested products against Callosobruchus maculatus adults according to the method described by Finney (1971).

Concentration mortality relationships were plotted on probit logarithmic transformation for each case studied. The slope values of established lines, $\mathrm{LC}_{25}, \mathrm{LC}_{50}, \mathrm{LC}_{75}, \mathrm{LC}_{90}, \mathrm{LC}_{95}$ and $\mathrm{LC}_{99}$ (for Callosobruchus maculatus) were estimated after $48 \mathrm{hrs}$ from insect exposure (Bliss, 1935).

Combination between Katel- sous dust \& clove powder:-

Katel-sous dust and clove powder were tested separately and in the following combinations Table (1).

Table 1: Mixture percentages between Katel- sous dust and the clove powder:

\begin{tabular}{|c|c|}
\hline No. of the mixtures & The percentages of the materials in each mixture \\
\hline Mixture No. (1) & $\mathrm{LC}_{50}$ Katel- sous $+\mathrm{LC}_{50}$ Clove powder \\
\hline Mixture No. (2) & $\mathrm{LC}_{25}$ Katel- sous $+\mathrm{LC}_{75}$ Clove powder \\
\hline Mixture No. (3) & $\mathrm{LC}_{75}$ Katel- sous $+\mathrm{LC}_{25}$ Clove powder \\
\hline Mixture No. (4) & $\mathrm{LC}_{25}$ Katel- sous $+\mathrm{LC}_{25}$ Clove powder \\
\hline
\end{tabular}

Evaluation the toxicity of the tested mixtures:

Evaluate toxicity of prepared mixtures against Callosobruchus maculatus adults by adding each of the forementioned mixtures to ten grams of cowpea seeds in $1 \times 7.5 \mathrm{~cm}$ glass tube kept at $27 \pm{ }^{\circ} \mathrm{C}$ and $65 \pm 5 \%$ RH. Batches of 25 adults of the tested insect were introduced into each tube, also untreated control was included. Three replicates were used for each mixture. Tubes were covered with plastic cover fixed with rubber band. Mortality was recorded after 2, 3 and 5 days. Percent insect mortality was corrected using Abbott's formula (1925), and computed according to Finney (1971). 
Biological aspects of Callosobruchus maculatus after treatment with the tested natural products:

Insects for the following experiments were maintained under constant conditions in an incubator set as previously mentioned.

Number of deposited eggs laid by Callosobruchus maculatus adults \& percentage hatchability:

To determine the number of eggs laid by mated female adults of Callosobruchus maculatus exposed to each of the tested products, $5 \mathrm{gm}$ of cowpea seeds treated with $\mathrm{LC}_{50}$ and $\mathrm{LC}_{95}$ (for insects) of each product were placed in glass tube measuring $1 \times 7.5 \mathrm{~cm}$ (each treatment had three replicates). Two pairs of newly emerged adults (18 hrs old) were placed in each tube and covered with plastic cover and kept in the incubator till death. After 10 days the insects were removed and the numbers of hatched and non hatched eggs were counted and were recorded and percent hatchability was determined and similar the reduction in hatchability was determined. Hatched eggs were defined by the presence of the larval frass, which causes the egg to turn milky white as neonate larvae bore into the seed or black color which was defined as the head capsule of the larva, while the non hatched eggs remain transparent and glossy (Giga and Smith, 1987). Thus the total numbers of white (or black) and translucent eggs on the seeds indicate bruchid oviposition and numbers of white eggs indicate the number of larvae entering the seed (Dharmasena et al., 2001).

To determine the effect of the mixtures on the number of deposited eggs, hatchability and $F_{1}$ progeny of Callosobruchus maculatus adults, five grams of cleaned cowpea seeds were mixed with the tested mixtures at the percentage values which mentioned before in Table (1) and then were placed in clean glass tubes measuring $1 \times 7.5$ cm. Two couples of newly emerged adults were placed in each tube which was covered with plastic cover. After ten days, dead insects were disregarded and the seeds were examined for the number of eggs laid. Hatchability of eggs were indicated when they turned white showing that eggs had hatched and larvae had penetrated the seeds (Salwa et al., 2001).

The above collected cowpea seeds bearing deposited eggs were placed in clean glass tubes and kept in an incubator under the aforementioned constant conditions till adult emergence.

\section{Percentage adult emergence:}

The infested treated seeds with eggs were incubated and observed regularly until adult emergence. Emerging adults were counted and discarded for a period of 10 days. The adult emergence (\%) was calculated from the number of hatched eggs and $F_{1}$ adult progeny and the reduction in $\mathrm{F}_{1}$ progeny was also calculated.

Infested seeds were maintained in glass tubes until offspring emerged, which were then counted and then the adult emergence percentage and the reduction in $F_{1}$ progeny emergence were calculated.

Three replicates were made for each mixture, also for control test three replicates of untreated seeds made.

Effect of clove powder on spiracles of Callosobruchus maculatus adults using scanning electron microscope:

Sample Collection and Preparation:

Minimal preparation includes acquisition of a sample that will fit into the SEM chamber and some accommodation to prevent charge buildup on electrically insulating samples. Most electrically insulating samples are coated with a thin layer of conducting material, commonly carbon, gold, or some other metal or alloy. The choice of material for conductive coatings depends on the data to be acquired. In our study we used gold as a conducting material by 
a machine called a sputter coater. Metal coating are most effective for high resolution electron imaging applications. Then the sample is placed inside the microscope's vacuum column through an air-tight door.

\section{RESULTS AND DISCUSSION}

Toxicological evaluation of katel-sous dust and clove powder and its mixtures on Callosobruchus maculatus (F.) adults:

Evaluation the toxicity of katel-sous dust and clove powder:

The results of the susceptibility tests of callosobruchus maculatus adults to clove powder and katel-sous dust, inert material $(84 \%$ calcium triphosphate + $16 \%$ sulpher) are presented in Table (2). The estimated toxicity values of $\mathrm{LC}_{25}$, $\mathrm{LC}_{50}, \mathrm{LC}_{75}, \mathrm{LC}_{95}$ and $\mathrm{LC}_{99}$ for katel-sous dust and clove powder are presented in Table (2), $\mathrm{LC}_{95}$ of katel-sous dust for cowpea seeds was 1.76 while $\mathrm{LC}_{95}$ of clove powder was 0.28 . The percentage mortality increase with the increase of concentration of each tested compound, i.e. a potential linear relationship between the concentrations and mortality percentages exists.

Katel-sous dust was a good grain protectant against Callosobrochus maculatus adults as the result evaluated by Abdel-Latif, (1999).

The highest concentration of clove gave $100 \%$ mortality with three days of exposure. Rajapakse, et al., (1998) found that clove powder gave the highest mean number of adult mortality of $C$. maculatus. Abdellah-Kellouche and Noureddine-Soltane, (2004) reported that among the tested botanicals, the clove powder was the most toxic to $C$. maculatus as adult survival in treated seeds, even at the lowest dosage of $1 \%$. Ntonifor, et al., (2010) found that clove powder treated grains caused $100 \%$ adult mortality of Callosobruchus maculatus.

Table 2: Corrected percentage mortality of Callosobruchus maculatus adults\& Collective toxicity data caused by katel-sous dust and clove powder after two days of exposure:

\begin{tabular}{|c|c|c|c|c|c|c|c|c|c|c|c|}
\hline \multirow[t]{2}{*}{ Treatments } & \multirow{2}{*}{$\begin{array}{l}\text { Conc } \\
\text {. (\%) } \\
\text { W/W }\end{array}$} & \multicolumn{4}{|c|}{$\begin{array}{l}\% \text { adult mortality after } \\
\text { indicated periods (days) }\end{array}$} & \multirow[t]{2}{*}{$\mathbf{L C}_{25}$} & \multirow[t]{2}{*}{$\mathbf{L C}_{50}$} & \multirow[t]{2}{*}{$\mathbf{L C}_{75}$} & \multirow[t]{2}{*}{$\mathrm{LC}_{95}$} & \multirow[t]{2}{*}{$\mathrm{LC}_{99}$} & \multirow{2}{*}{$\begin{array}{c}\text { Slope of } \\
\text { Regressio } \\
\text { n line }\end{array}$} \\
\hline & & $1^{\text {st }}$ & $2^{\text {nd }}$ & $3^{\text {rd }}$ & $5^{\text {th }}$ & & & & & & \\
\hline \multirow{5}{*}{$\begin{array}{c}\text { Katel- sous } \\
\text { dust }\end{array}$} & 0.1 & 12 & 22.6 & 49.3 & 100 & \multirow{5}{*}{0.14} & \multirow{5}{*}{0.3} & \multirow{5}{*}{0.62} & \multirow{5}{*}{1.76} & \multirow{5}{*}{3.7} & \multirow{5}{*}{$\begin{array}{c}2.1189 \pm \\
0.2266\end{array}$} \\
\hline & 0.3 & 14.6 & 32 & 64 & 100 & & & & & & \\
\hline & 0.4 & 20 & 60 & 89.3 & 100 & & & & & & \\
\hline & 0.5 & 28 & 73.3 & 96 & 100 & & & & & & \\
\hline & 0.7 & 46.7 & 85.3 & 97.3 & 100 & & & & & & \\
\hline \multirow{5}{*}{$\begin{array}{c}\text { Eugenia } \\
\text { aromatica } \\
\text { (Clove } \\
\text { powder) }\end{array}$} & 0.03 & 12 & 20 & 36 & 58.7 & \multirow{5}{*}{0.04} & \multirow{5}{*}{0.06} & \multirow{5}{*}{0.09} & \multirow{5}{*}{0.18} & \multirow{5}{*}{0.28} & \multirow{5}{*}{$\begin{array}{c}3.4172 \pm \\
0.2938\end{array}$} \\
\hline & 0.05 & 18.7 & 33.3 & 42.7 & 68 & & & & & & \\
\hline & 0.07 & 26.6 & 54.6 & 64 & 84 & & & & & & \\
\hline & 0.1 & 41.3 & 82.6 & 93.3 & 100 & & & & & & \\
\hline & 0.2 & 54.6 & 97.3 & 100 & - & & & & & & \\
\hline
\end{tabular}

The slope of regression lines obtained after 2 days of treatment indicate that clove powder at both $\mathrm{LC}_{50}$ and $\mathrm{LC}_{95}$ levels have the steeper toxicity lines. The slope of toxicity lines indicated that, the highest insect sensitivity to gradual increased concentrations was exhibited by clove powder. This result is agreed with Salwa, 
(1992), Zidan et al., (1993) \& Rohan, et al., (2002).

Evaluation the toxicity of the tested mixtures:

Mortality values (\%) of the cowpea beetle, Callosobruchus maculatus adults exposed to the tested mixtures of clove powder with katel-sous are given in Table (3).
By making comparison between the mixtures it showed that mixture 3 showed $100 \%$ mortality from the second day of exposure. Mixtures 1, 2 and 4 gave $98.7 \%, 96 \%$ and $60 \%$ respectively.

All the tested mixtures were also very effective in suppressing the survival of $C$. maculatus adults when applied at the concentrations used.

Table 3: Corrected percentage mortality of Callosobruchus maculatus adults treated with different mixtures of natural powders with Katel-sous at different concentrations:

\begin{tabular}{|c|c|c|c|c|}
\hline \multirow{6}{*}{$\begin{array}{l}\text { The combination of katel-sous dust } \\
\text { with the clove powder }\end{array}$} & \multirow[t]{2}{*}{ Mixtures } & \multicolumn{3}{|c|}{$\begin{array}{l}\text { \% Adults mortality after indicated } \\
\text { period (days) }\end{array}$} \\
\hline & & 2 days & 3 days & 5 days \\
\hline & $\begin{array}{c}\text { Mix. No. } 1 \\
\text { LC }_{50} \text { katel- sous }+\mathrm{LC}_{50} \text { clove }\end{array}$ & 98.7 & 100 & - \\
\hline & $\begin{array}{c}\text { Mix. No. } 2 \\
\text { LC }_{25} \text { katel- sous }+\mathrm{LC}_{75} \text { clove }\end{array}$ & 96 & 100 & - \\
\hline & $\begin{array}{c}\text { Mix. No. } 3 \\
\text { LC }_{75} \text { katel- sous }+\mathrm{LC}_{25} \text { clove }\end{array}$ & 100 & - & - \\
\hline & $\begin{array}{c}\text { Mix. No. } 4 \\
\mathrm{LC}_{25} \text { katel- sous }+\mathrm{LC}_{25} \text { clove }\end{array}$ & 60 & 72 & 92 \\
\hline
\end{tabular}

In the present investigation the tested mixtures as compared with the clove powder has demonstrated that the mixtures caused significant mortalities better than clove alone. So, it can be said that the combination between two products gave better results. This was in agreement with (Govindan and Nelson, (2008), Ntonifor et al., (2010) \& Durga Singh and Srivastava, (2011).

On the other hand, the using of katel-sous alone gave high effect better than the mixtures but it is not preferred to use it because of its high concentration and its high weight. So the present study is a trial to mix katel-sous dust with clove powder to get best results Abdel-Latif, (1999).

Mixture 3 which have $75 \%$ katelsous gave $100 \%$ mortality of the adults of the tested insects from the second day.

The order of the other mixtures according to the mortality caused by them is mix. $1>$ mix. $2>$ mix. 4 .
Biological aspects of Callosobruchus maculatus after treatment with the tested natural products:

Number of deposited eggs laid by Callosobruchus maculatus adults \& percentage hatchability:

Katel-sous dust significantly reduced the oviposition and the number of eggs laid by C. maculatus female adults (Table $4 \&$ Fig. 1).

In case of treatment with clove powder, the insect did not lay any egg on the surface of cowpea seeds. However, with katel-sous dust the mean number of hatched eggs was 41 eggs/ female. The mean number of eggs laid by one female in untreated control sample was 92 eggs/ female, 91 from them were hatched.

98.9\% hatchability observed with the untreated control, while 90, 87.2, 0, $0 \%$ for katel-sous $\mathrm{LC}_{50}$, katel-sous $\mathrm{LC}_{95}$, clove $\mathrm{LC}_{50}$ and clove $\mathrm{LC}_{95}$ respictively. 
Table 4: Efficacy of the katel-sous dust and clove powder on the oviposition and hatchability of eggs and on adult emergence $\%$ of Callosobruchus maculatus.

\begin{tabular}{|c|c|c|c|c|c|c|c|c|c|c|c|c|c|c|c|}
\hline \multirow{3}{*}{$\begin{array}{c}\text { Tested } \\
\text { powder }\end{array}$} & \multirow{3}{*}{ Conc. } & \multicolumn{9}{|c|}{ Mean no. of eggs / female } & \multicolumn{5}{|c|}{ Progeny emergence } \\
\hline & & \multicolumn{2}{|c|}{ 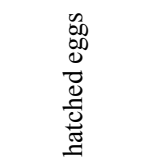 } & \multicolumn{2}{|c|}{ 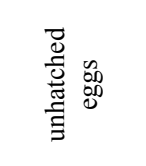 } & \multirow[t]{2}{*}{ 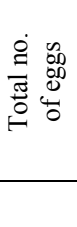 } & \multicolumn{2}{|c|}{ 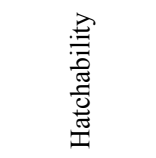 } & \multicolumn{2}{|c|}{ 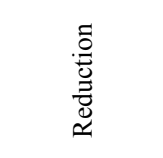 } & \multirow[t]{2}{*}{$\begin{array}{l}\dot{0} \\
z \\
0 \\
\frac{0}{\tilde{Z}} \\
0 \\
01\end{array}$} & \multirow[t]{2}{*}{$\begin{array}{l}\dot{0} \\
z \\
0 \\
\frac{0}{\pi}\end{array}$} & \multirow[t]{2}{*}{ 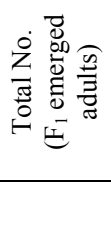 } & \multirow[t]{2}{*}{ 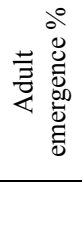 } & \multirow[t]{2}{*}{$\begin{array}{l}\partial^{\circ} \\
\dot{0} \\
\simeq\end{array}$} \\
\hline & & No. & S.D & No. & S.D & & $\%$ & S.D & $\%$ & S.D & & & & & \\
\hline Katel-sous & $\begin{array}{l}\mathrm{LC}_{50} \\
\mathrm{LC}_{95}\end{array}$ & $\begin{array}{l}36 \\
41 \\
\end{array}$ & 3.5 & $\begin{array}{l}4 \\
6 \\
\end{array}$ & 1.4 & $\begin{array}{l}40 \\
47 \\
\end{array}$ & $\begin{array}{c}90 \\
87.2\end{array}$ & 1.97 & $\begin{array}{c}59.3 \\
54.95 \\
\end{array}$ & 3.1 & $\begin{array}{l}15 \\
13 \\
\end{array}$ & $\begin{array}{c}10 \\
9\end{array}$ & $\begin{array}{l}25 \\
22 \\
\end{array}$ & $\begin{array}{l}69.4 \\
53.7 \\
\end{array}$ & $\begin{array}{c}69.13 \\
72.8 \\
\end{array}$ \\
\hline $\begin{array}{c}\text { Eugenia } \\
\text { aromatica }\end{array}$ & $\begin{array}{l}\mathrm{LC}_{50} \\
\mathrm{LC}_{95} \\
\end{array}$ & $\begin{array}{l}0 \\
0 \\
\end{array}$ & 0 & $\begin{array}{l}0 \\
0 \\
\end{array}$ & 0 & $\begin{array}{l}0 \\
0 \\
\end{array}$ & $\begin{array}{l}0 \\
0 \\
\end{array}$ & 0 & $\begin{array}{l}100 \\
100 \\
\end{array}$ & 0 & $\begin{array}{l}0 \\
0 \\
\end{array}$ & $\begin{array}{l}0 \\
0 \\
\end{array}$ & $\begin{array}{l}0 \\
0 \\
\end{array}$ & $\begin{array}{l}0 \\
0 \\
\end{array}$ & $\begin{array}{l}100 \\
100 \\
\end{array}$ \\
\hline Control & & 91 & 0 & 1 & 0 & 92 & 98.9 & 0 & 0 & 0 & 46.7 & 34.7 & 81.3 & 89.34 & 0 \\
\hline
\end{tabular}

The mixtures 1 and 2 totally total number of eggs/ female. This prevented the females to lay eggs. The reduction was $78.92 \%$ Table 5 \& Fig. 1 . mixture 3 showed highly reduction in

Table 5: Efficacy of the tested mixtures on oviposition and hatchability percentage of Callosobruchus maculatus adults.

\begin{tabular}{|c|c|c|c|c|c|c|c|c|c|c|}
\hline \multirow[b]{2}{*}{ Treatments } & \multicolumn{5}{|c|}{ Mean No. of eggs / female } & \multicolumn{5}{|c|}{ Progeny emergence } \\
\hline & 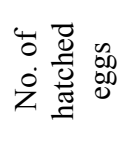 & 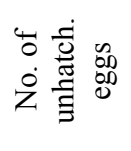 & 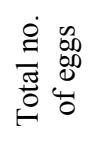 & 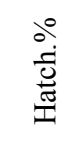 & $\begin{array}{l}\stackrel{0}{ } \\
\dot{0} \\
\mathscr{\alpha}\end{array}$ & 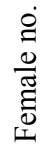 & $\begin{array}{l}\dot{0} \\
\frac{0}{\pi} \\
\sum\end{array}$ & 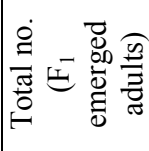 & 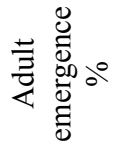 & $\begin{array}{l}\stackrel{2}{0} \\
\ddot{0} \\
\approx\end{array}$ \\
\hline $\begin{array}{c}\text { Mix. No. } 1 \\
\text { LC }_{50} \text { katel- } \\
\text { sous }+ \text { LC }_{50} \\
\text { clove }\end{array}$ & 0 & 0 & 0 & 0 & 100 & 0 & 0 & 0 & 0 & 100 \\
\hline $\begin{array}{c}\text { Mix. No. } 2 \\
\text { LC }_{25} \text { katel- } \\
\text { sous }+\mathrm{LC}_{75} \\
\text { clove }\end{array}$ & 0 & 0 & 0 & 0 & 100 & 0 & 0 & 0 & 0 & 100 \\
\hline $\begin{array}{c}\text { Mix. No. } 3 \\
\text { LC }_{75} \text { katel- } \\
\text { sous }+ \text { LC }_{25} \\
\text { clove }\end{array}$ & 18.7 & 18.7 & 37.3 & 50.13 & 78.92 & 5 & 9 & 14 & 74.86 & 76.9 \\
\hline Control & 88.7 & 21 & 109.7 & 80.86 & 0 & 53 & 29.7 & 82.7 & 93.2 & 0 \\
\hline
\end{tabular}

There was a great reduction in egg laying (zero eggs were laid) in case of clove powder treatment. This was in agreement with Adebayo and Gbolade, 1994; Lawal, (2001); Salwa, (2002); Ajayi and Wintola, (2006) \& Javaid and Poswal, (1995) reported that clove powder gave results which were not significantly different from those produced by malathion.

In case of the mixtures of katelsous dust and clove powder, some eggs were recorded with mixture 3 and no eggs for mixtures $1 \& 2$. This result may be due to the high concentration of katelsous in the mixture $3(75 \%)$.

\section{Percentage adult emergence:}

The highest concentration ( $\left.\mathrm{LC}_{95}\right)$ of katel-sous dust significantly reduced the number of $F_{1}$ emerged adults to 22 and 25 in lowest concentration $\left(\mathrm{LC}_{50}\right)$ compared with 81.3 in the untreated seeds. There is no adults emerged with clove powder due to preventing the adults to lay eggs on the seeds.

There was significant difference in number of $C$. maculatus emerged adults when treated with different mixtures (Table 5\& Fig. 1). The highest number of 
total emerged adults was observed in mixture $3,75 \%$ katel-sous $+25 \%$ clove, (37.3), while in control 109.7 eggs were observed. Zero emerged adults were observed in mixture 1 (25\% katel-sous + $75 \%$ clove $)$ and mixture $2(50 \%$ katelsous $+50 \%$ clove).

The $\mathrm{F}_{1}$ emerged adults of the tested insect $C$. maculatus decreased significantly in the treated seeds with mixture no. 3 (Table 5 \& Fig. 1), the percentage adult emergence in this mixture was $74.86 \%$. The reduction in the adult emergence in the mixtures no. 1 and 2 were $100 \%$ due to there is no eggs laid by the tested insect adults with the pervious mixtures.

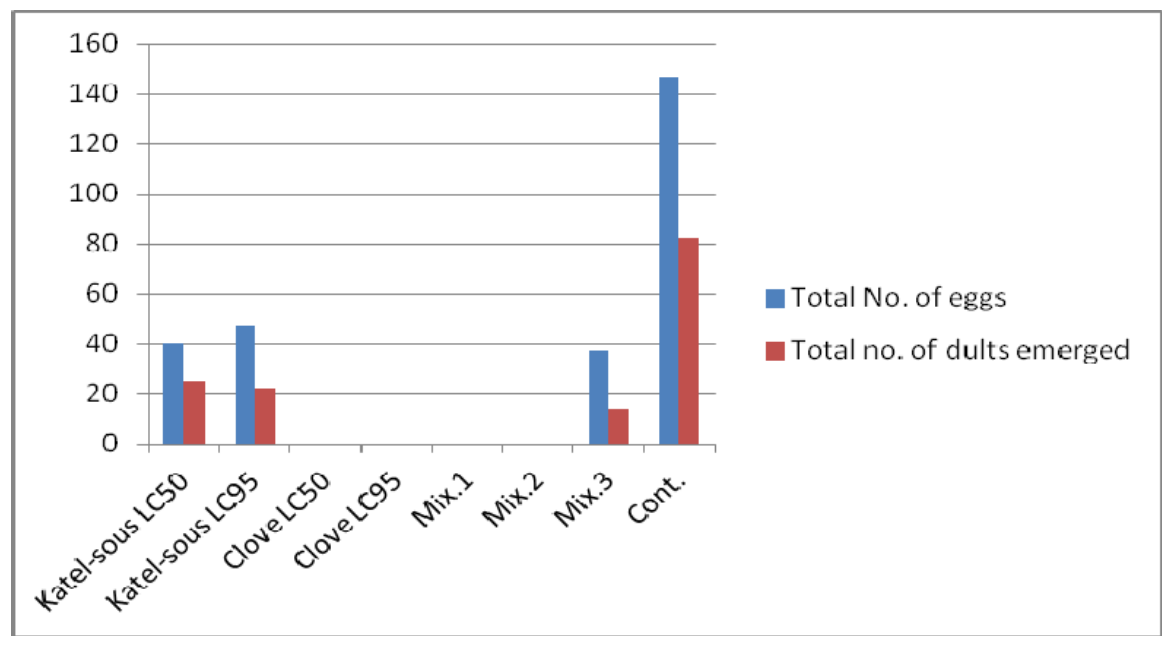

Fig. 1: Total number of eggs and adults emerged after treatment with the katel-sous dust, clove powder and their mixtures.

Results showed a negative correlation between the numbers of $F_{1}$ emerged adults and the concentration of katel-sous dust (increasing the concentration reduces the number of $F_{1}$ emerged adults).

As a result of preventing egg laying by clove there was no adults emerged with this treatments. There was a significantly reduction in hatchability and adult emergence with the natural products and this is in agreement with Taheya et al., (1996), Halawa et al., (1998) \& Ajayi and Wintola, (2006).

Mixture 1, mixture 2 showed 100\% reduction in the adult emergence as well as in egg laying. Mixture 3 showed high significant decrease in the adult emergence compared with control Fig. (1).

Similar results obtained with Govindan and Nelson, (2008) who reported that the number of eggs laid by female, hatchability per cent and adult emergence of Callosobruchus maculatus of the black gram seeds treated with mixtures of plant powder were significantly difference from each other.

Effect of clove powder on spiracles of Callosobruchus maculatus adults using scanning electron microscope:

Spiracles are external openings found in some animal species, such as insects, spiders and some species of fish and whales. The function of spiracles is linked to respiration, helping oxygen to reach internal respiratory organs, tracheae in insects. In Callosobruchus maculatus adults these organs are located in the abdomen.

\section{Untreated Sample:}

The spiracles of the C. maculatus adults appeared on the side of the abdomen as shown in Fig. (2) (The SEM shows very detailed 3-dimensional images at much higher magnifications 
than is possible with a light microscope). The opened spiracles (breathing opens) represented in Fig. (3).

\section{Treated Sample:}

Spiracles were closed in Fig. (4) after treatment with clove powder.

Treatment with clove powder leads to the closure of spiracles of the Callosobruchus maculatus adults and this leads to suffocation of the insect and thus causing death. While in the untreated sample the spiracles were clearly opened.

So it can be concluded that clove powder as spiracle-blocking insecticides which are highly effective against major pests, such as thrips, aphids, whiteflies and spider mites (Matsuda et al., 1995; Motegi, 2001; Hondo et al., 2001; Ota, 2008).

\section{REFERENCES}

Abbott, W.S. (1925): A method of computing the effectiveness of an insecticide. J. Entomol., 18 (2): 265 267.

Abdellah-Kellouche and Noureddine-Soltani (2004): Biological activity of powders of five plants and the essential oil of one of them on Callosobruchus maculatus (F.). Internat.-J.-Trop.Insect-Sci. 24(2): 184-191.

Abdel-Latif, A. M. (1999): Effectiveness of Agrothrin ( $0.11 \%$ pyrethrum) and its mixtures with some grain protectants against the cowpea beetle Callosobruchus maculatus (F.). Ann. Agric. Sci. Moshtohor 37 (2): 14111423.

Adebayo, T. and Gbolade, A. A. (1994): Protection of stored cowpea from Callosobruchus maculatus using plant products. Insect Science and its Application 15(2): 185-189.

Ajayi, F. A. and Wintola, H. U. (2006): Suppression of the cowpea bruchid (Callosobruchus maculatus F.) infesting stored cowpea (Vigna unguiculata (L.) Walp.) seeds with some edible plant product powders. Pakistan J. of Biol. Sci., 9 (8): 14541459.

Alexander, P.; Kitchener J. A., and Briscoe H. V. A. (1944): Inert dust insecticides. Part I. Mechanism of action. Ann. Appl. Biol. 31: 143-149.

Bliss, C. J. (1935): The calculation of dosage mortality curve. Ann. App. Biol., 22 (1): 134-167.

Caswell, G. H. (1968): The storage of cowpea in Northern States of Nigeria. Proc. Agric. Soc. of Nigeria, Vol. 5, pp.4-5.

Caswell, G. H. (1981): Damage to stored cowpeas in northern Nigeria. Samaru J. Agric. Res., 1: 11-19.

Dharmasena, C. M. D.; Blaney W. M. and Simmonds M. S. G. (2001): Effect of storage on the efficacy of powdered leaves of Annona squamosa for the control of Callosobruchus maculatus on cowpea (Vigna unguiculata). Phytoparasitica, 29 (3): 1-6.

Dixit, O. P. and Saxena R. C. (1990): Insecticidal action of Premina intgrifolia against Callosobruchus chinensis. Pesticides, 24: 29-31.

Durga S. and Srivastava, A. K. (2011): Efficacy of indigenous plant products against pea weevil (Callosobruchus chinensis) in stored greengram (Vigna radiata). Ind. J. Agric. Sci. 81: 1, 9496.

El- Bandy, M. A.; El- Zemaity M. S.; Ebaid N. M. and Salama S. I. (1985): Effect of some bruchid beetles on weight loss, germination and moisture contents of certain leguminous seeds. Annals Agric. Sci. Fac. Agric.,Ain shams Univ., Cairo, Egypt, 30 (2): 1259-1275.

Finney, D. J. (1971): "Probit Analysis". Cambridge University Press, Cambridge, London, 333pp.

Giga, D. P. and Smith R. H. (1987): Egg production and development of Callosobruchus rhodesianus (Pic.) and Callosobruchus maculatus (F.) (Coleoptera: Bruchidae) on several commodities at two different temperatures. J. Stored Prod. Res. 23: 9-15.

Govindan, K. and Nelson, S. J. (2008): Effect of mixtures of plant powder against pulse beetle, Callosobruchus maculatus (F.) (Coleoptera: Bruchidae). J. Plant Prot. and Environ. 5: 1, 52-57. 
Halawa, Z. A.; Mohamed R. A. and ElKashlan, I. H. (1998): Laboratory evaluation of some plants and insecticides against the beetle Callosobruchus maculatus F. Infesting stored products. Egypt. J. Agric. Res. 76 (1): 85-94.

Hondo, M.; Tanaka, N. and Sato, E. (2001): Characteristic advantages and effective application of Nenchaku$\mathrm{Kun}^{\circledR}$, compatible plant protection material for integrated farm system. Sumitomo Chem., 1: 33-37.

Javaid, I. and Poswal, M. A. T. (1995): Evaluation of certain spices for the control of Callosobruchus maculatus (Fabricius) (Coleoptera: Bruchidae) in cowpea seeds. African-Entomol. 3(1): 87-89.

Lawal, O. A. (2001): Effectiveness of Dennttia tripetala and Eugenia aromatica on stored cowpea (Vigna unguiculata) seed against infestation by Callosobruchus maculatus. Ind. J. Agric. Sci., 71 (3): 180-182.

Matsuda, M.; Miyata, T. and Y. Takagi (1995): Insecticidal activities and mechanism of sodium oleate. Plant Prot., 49: 50-53.

Motegi, A. (2001): The properties of novel acaricide, propyleneglycol fatty acid monoester emulsifiable concentrate. Usage Acaritouch Plant Prot., 55: 554-557.

Ntonifor, N. N.; Oben, E. O. and Konje, C. B. (2010): Use of selected plantderived powders and their combinations to protect stored cowpea grains against damage by Callosobruchus maculatus. J. Agric. and Biol. Sci. 5: 5, 13-21.

Ota, Y. (2008): Mode of action of the hydrogenated starch hydrolysate. Plant Prot., 62: 619-623.

Park, C.; Kim, S. I. and Ahn, Y. J. (2003): Insecticidal activity of asarones identified in Acorus gramineus rhizome against three coleopteran stored-product insects. J. Stored Prod. Res., 39(3):333-342.

Rajapakse, R.; Senanayake, S. G. J. N. and Ratnasekera, D. (1998): Effect of five botanicals on oviposition, adult emergence and mortality of Callosobruchus maculatus Fabr. (Coleoptera: Bruchidae) infesting cowpea, Vigna unguiculata L. Walp. J. Entomol. Res. 22: 2, 117-122.

Rohan R.; Rajapakse H. L. de. Z. and Disna Ratnasekera (2002): Effect of botanicals on oviposition, hatchability and mortality of Callosobruchus maculatus (Coleoptera: Bruchidae). Entomon. 27 (1): 93-98.

Salwa, M. S. A. (1992): Biological activity of certain natural products on some stored grain insects.Ph.D. Agric. (Entomology), Ain Shams Univ.

Salwa, M. S. A. (2002): Evaluation of wild mint Menta longifolia and colve Eugenia aromatica powders for the control of Callosobruchus maculatus (F.) and Sitophilus oryzae (L.). Fayoum J. Agric., Res. \& Dev. Vol. 16(1): 30-39.

Salwa, M. S. A.; Sawsan, A. S. and Kassis, S. R. (2001): Evaluation of Brassica rapa (Rape) seed extract for the control of cowpea beetle, Callosobruchus maculatus (F). Arab Univ. J. Agric. Sci. 9(1): 433-445.

Taheya, S. M.; Sanaa, M. M. and Salwa, M. S. A. (1996): Efficiency of certain plant powders against the cowpea weevil Callosobruchus maculatus (F.) Coleoptera, Bruchidae. Egypt. J. Agric. Res., 74 (2): 307- 320.

Wigglesworth, V. B. (1944): Action of inert dusts on insects. Nature (Lond.) 153: 493-494.

Zidan, Z. H.; Gomaa, A. A.; Afifi, F. A.; Fam, E. Z. and Ahmed, S. M. S. (1993): Bioresidual activity of certain plant extracts on some stored grain insects, in relation to seed viability. Arab-Univ.-J.- Agric.-Sci. 1(1): 113123. 


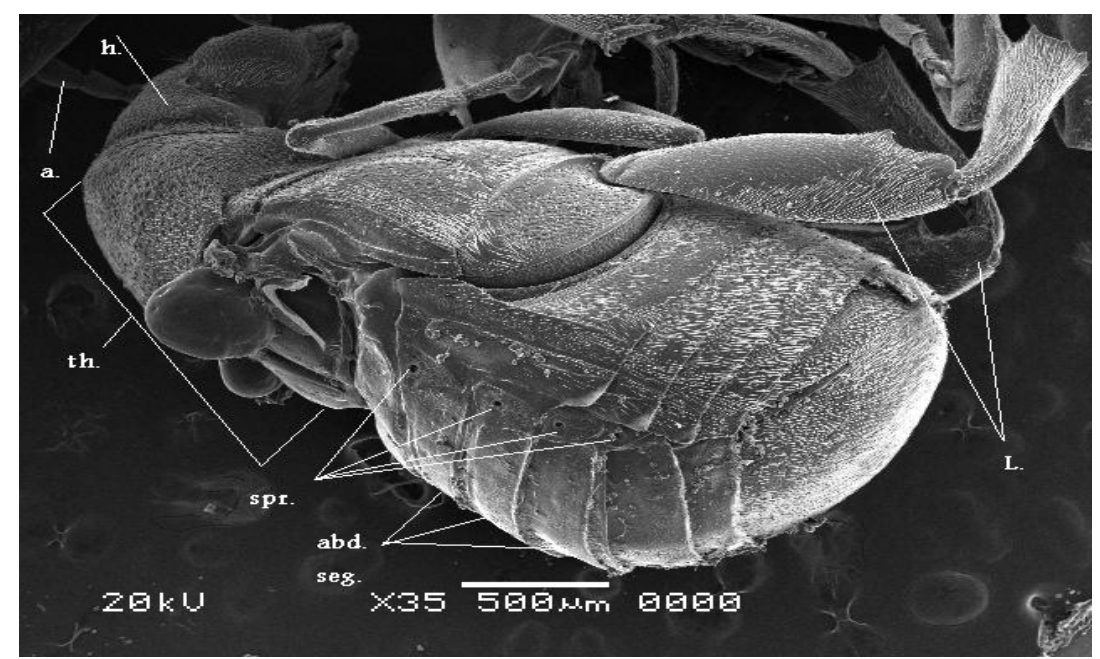

Fig. 2: The Scanning Electron Microscope (SEM) shows very detailed 3-dimensional images showing the normal spiracles on the abdomen of the untreated Callosobruchus maculatus adults.

Antenna (a.), head (h.), thorax (th.), spiracles (spr.), abdominal segments (abd. seg.) \& legs (L.).

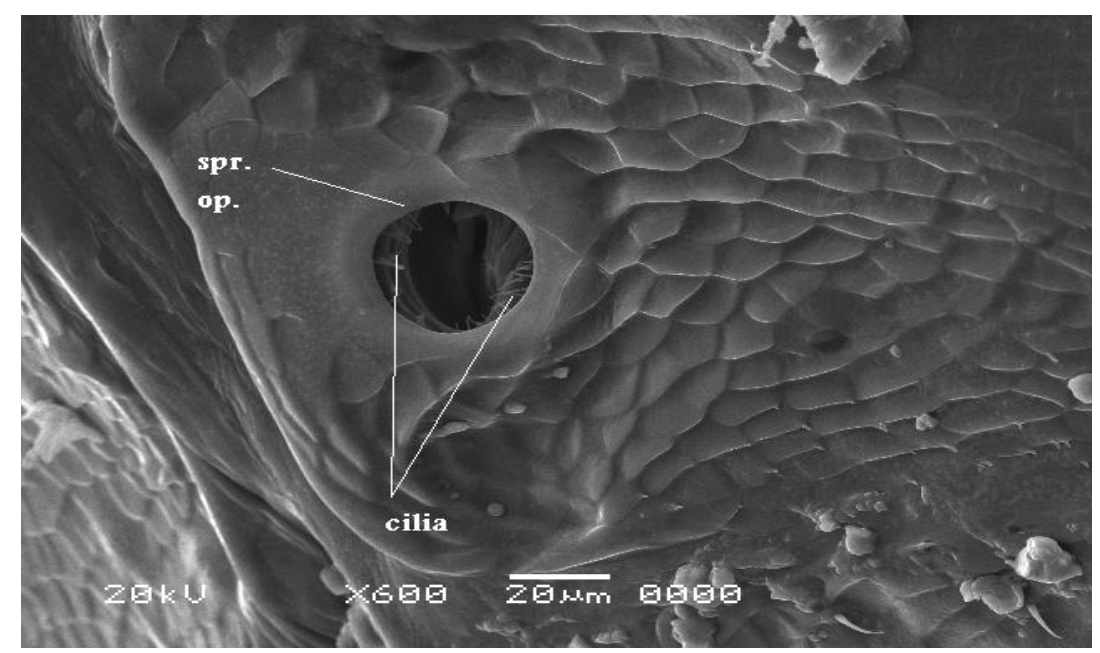

Fig. 3: Spiracle openings on the abdomen and the cilia which surround the spiracle openings of the untreated Callosobruchus maculatus adults. Spiracle openings (spr. op.).

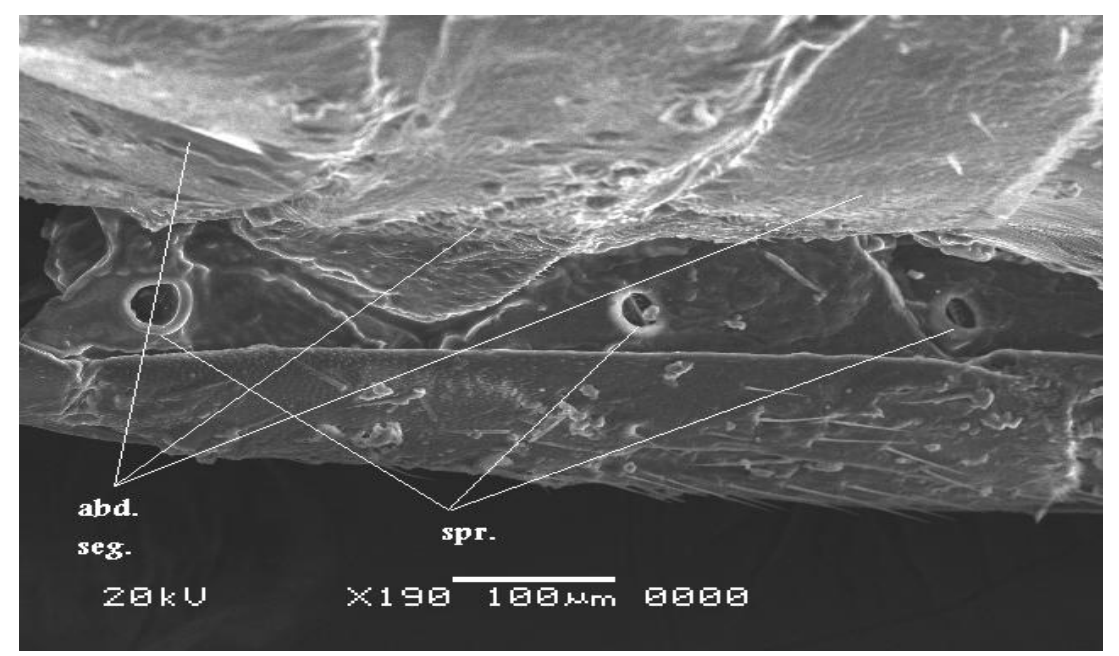

Fig. 4: The closed spiracles on the abdomen of Callosobruchus maculatus adults after treatment with clove powder. Abdominal segments (abd. seg.) and spiracles (spr.). 


\section{ARABIC SUMMARY}

تأثير قاتل السوس ومسحوق القرنفل ومخاليطهما على خنفساء اللوبيا (كالوزوبروكاس ماكيولاتس)

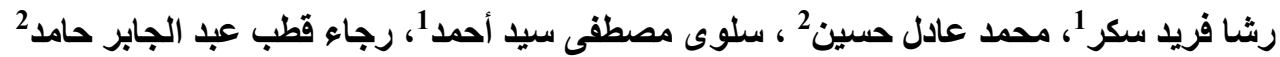

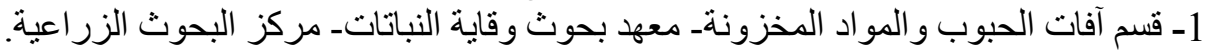
2- ـ قسم علم الحشر اتــ كلية العلوم - جامعة عين شمس. اشتملت الدر اسة الحاليه على :

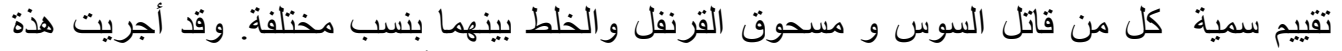

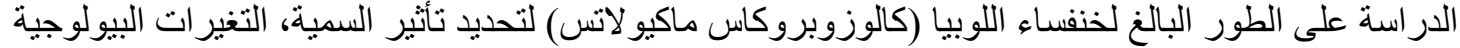

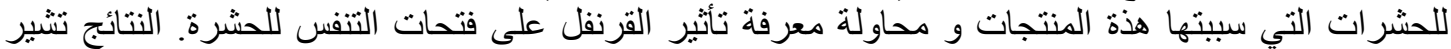

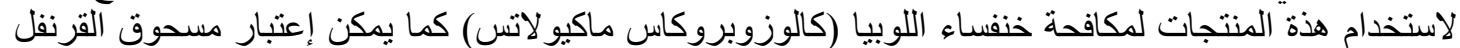

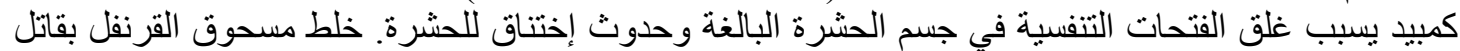

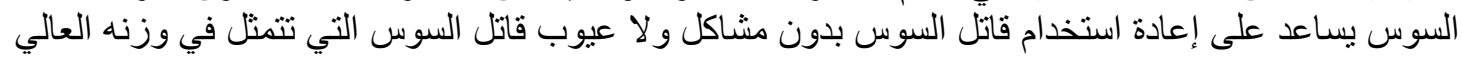

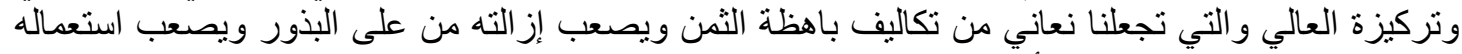

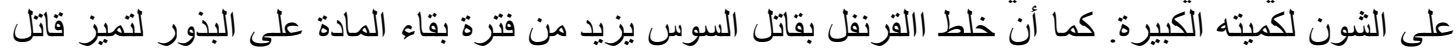
السوس بفترة بقاء عالية على البذور. 